
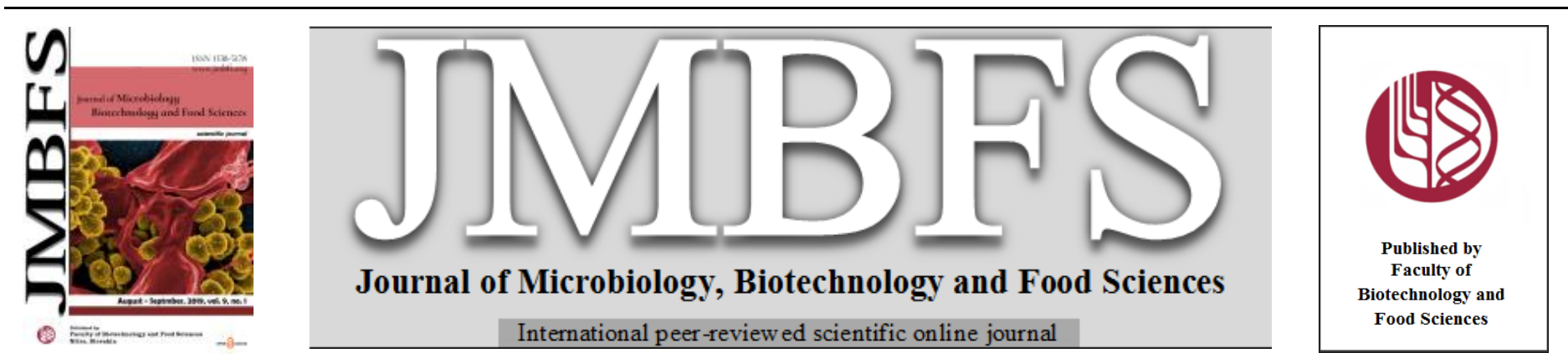

\title{
NEW RECORDS OF CORTICOLOUS MICROALGAE AND CYANOBACTERIA FOR PHILIPPINE ALGAL FLORA FROM MT. MAKILING FOREST RESERVE
}

\author{
Eldrin DLR. Arguelles*
}

\section{$\operatorname{Address(es):~}$}

Philippine National Collection of Microorganisms, National Institute of Molecular Biology and Biotechnology (BIOTECH), University of the Philippine Los Baños, College, Laguna, Philippines, 4031

*Corresponding author: edarguelles@up.edu.ph

doi: 10.15414/jmbfs.2019.9.1.1-8

\section{ARTICLE INFO}

Received 17. 4. 2018

Revised 15. 2. 2019

Accepted 18. 2. 2019

Published 1. 8. 2019

Regular article

open $\partial$ ACcess

\begin{abstract}
Diversity and species composition of corticolous microalgae and cyanobacteria from Mt. Makiling Forest Reserve showed the occurrence of 15 taxa belonging to the class Cyanophyceae, Chlorophyceae, Trebouxiophyceae, Ulvophyceae, and Klebsormidiophyceae. The collection reported in this study represents 12 orders, 13 families, 14 genera and 15 species based on morphotaxonomic characterization supported by microscopic studies. Of these taxa, the occurrence of six corticolous algae namely: Chroococcidiopsis cubana Komárek \& Hindák, Pseudanabaena galeata Böcher, Pseudanabaena catenata Lauterborn, Parachlorella kessleri (Fott \& Nováková) L. Krienitz, E.H. Hegewald, Hepperle, V. Huss, T. Rohr \& M. Wolf, Desmococcus olivaceus (Persoon ex Archerson) J. R. Laundon, and Apatococcus lobatus (Chodat) J.B. Petersen are reported for the first time in the Philippines. These taxonomic records are considered important information in enhancing our knowledge about the diversity and habitat distribution of this important group of primary producers found in forest reserves of the Philippines.
\end{abstract}

Keywords: Corticolous algae, diversity, Mt. Makiling Forest Reserve, new record, taxonomy, Philippines

\section{INTRODUCTION}

Corticolous microalgae and cyanobacteria are considered dwellers of the bark of trees from the areas of different altitudes. These organisms can be observed as greenish or dark, gelatinous, red dark or brown patches, streaks or velvet masses and are exposed to air and absorb water, minerals and other nutrients directly from the atmosphere (Bhakta, et al., 2014). The environment from which these algae are found is regarded as extreme because of their minimal water resources or their extremely low or high temperature and light levels. These algae have developed distinct morphological and physiological adaptations in order to survive and proliferate under such extreme condition (Lemes-da-Silva, et al., 2010). The occurrence of small $(5-15 \mu \mathrm{m})$, unicellular, coccoid microalgal taxa in tree bark biofilms is an example of morphology-based functional adaptation of the corticolous algae to frequent desiccation, high irradiance and temperature fluctuations (Ettl and Gätner, 2013; Lopez-Bautista et al., 2007; Štifterová and Neustupa, 2015). In addition to morphological adaptations, the constituents of the phototrophic aerial biofilms also hold diverse eco-physiological strategies, such as high intracellular osmotic values to prevent water loss to recurrent dry/rehydration cycles and photoprotection for survival in habitat with high UV levels (ك̌tifterová and Neustupa, 2015).

The tropical rainforest is considered as one of the most diverse naturally occurring habitat on Earth that should be conserved. The wide variability of distinct and unique landscapes in this biological community can explain the high number of endemic organisms, which is also true for microorganisms, including microalgae and cyanobacteria. Several studies on taxonomy and ecology of aerophytic corticolous algae were conducted in temperate and other tropical countries with great emphasis on those occurring on forest areas (Salleh and Millow, 1999; López-Bautista et al., 2006; Neustapa and Škaloud, 2008; Lemes-da-Silva et al., 2010; Zammit et al., 2011; Neustapa and Štifterová, 2010; Štiferová and Neustupa, 2015). While recent studies indicate a high taxonomic diversity of corticolous algae in the tropical regions of the world equaling or even surpassing that of temperate areas, studies of corticolous algae in these regions remain rare and Philippines is no exception. This important microflora is still very poorly known in the Philippines due to the lack of exploration and seasonal collection of samples. Hence, the present survey was carried out to assess the diversity of corticolous algae from Mt. Makiling Forest Reserve. This paper aims to add to our knowledge of the taxonomy, diversity and habitat distribution of corticolous algae present in corticolous communities found in a conserved tropical forest in Luzon, Philippines.

\section{MATERIAL AND METHODS}

\section{Sampling of Corticolous Algae}

A single preliminary collection was made to Mt. Makiling Forest Reserve (situated at $14^{\circ} 08^{\prime} \mathrm{N}, 121^{\circ} 11^{\prime} \mathrm{E}$ ) to study the occurrence of corticolous algal flora occurring on trees on December 2017. The bark of 14 trees with a trunk diameter of more than $30 \mathrm{~cm}$ was sampled for surface microbial growths at a height of $120-40 \mathrm{~cm}$ above the soil level, evenly around the trunk perimeter. All samples were collected in sterile specimen tubes (Tarson) of 25 X $50 \mathrm{~mm}$ size using clean sampling bottles, forceps, polythene bags, brush, petri dish, scalpel etc. and brought to the laboratory for further analysis.

\section{Micrometry, Photomicrography, and Identification}

The algal biofilm was abraded off the samples with a sterile scalpel and placed into $1.5 \mathrm{ml}$ Eppendorf tubes containing $0.5 \mathrm{ml}$ liquid Blue-Green Medium (BG 11). Then, sterile glass beads $(0.5 \mathrm{~mm}$ in diameter $)$ were placed in the tube, which was mixed for 15 seconds at $1200 \mathrm{rpm}$ in a vortex mixer (Štifterová and Neustupa, 2015). The homogenized samples were placed in Petri dishes within $72 \mathrm{~h}$ after the collection. They were cultivated on BG11 medium (Stainer et al., 1971) at a temperature of $25^{\circ} \mathrm{C}$ and an illumination of $40 \mu \mathrm{mol} \mathrm{m}^{-2} \mathrm{~s}^{-1}$ provided by 18W cool fluorescent tubes (Philips TLD 18W/33) (Arguelles, et al., 2018). After growth, each filament, colony or a consortium was taken for photomicrography. Microphotographs were taken with AO Spencer microscope and Olympus CX31 binocular research microscope (Arguelles et al., 2014). The morphological features pertinent to morphotaxonomic identification such as the size and shape of vegetative cells as well as specialized cells (heterocytes and akinetes); characteristics of the filaments and trichomes, presence or absence of constriction at the cross wall; presence or absence of sheath, color and appearance of the sheath; and absence or presence of specialized cells such as heterocytes and akinete were recorded during the enumeration, identification and classification of each algal species. The algal species were identified using the monographs and standard works of literature as follows: (Desikachary, 1959; Presscott, 1962; Velasquez, 1962; Komárek and Anagnostidis, 2005; 
McGregor, 2007; Whitton, 2011 and Ettl and Gartner, 2013) Morphotaxonomic identification was done up to the species level using al available information. In the present study, the orthographs 'hormogonia' and 'heterocytes' instead of 'hormogones' and 'heterocysts' respectively were used, as suggested by the International Association for Cyanophyte Research (IAC) (Mollenhauer et al., 1994).

\section{RESULTS AND DISCUSSION}

The study revealed 15 taxa belonging to the class Cyanophyceae, Chlorophyceae, Trebouxiophyceae, Ulvophyceae, and Klebsormidiophyceae. Morphotaxonomy of each of the isolates is presented together with a short description of the place of collection and habitat of their occurrence. Current names were used based on Guiry and Guiry (2018). All scale bars $=10 \mu \mathrm{m}$.

\section{Taxonomic Enumeration}

\section{Cyanobacteria}

Class Cyanophyceae

Order Chroococcales

Family Aphanothecaceae

Genus Gloeothece C. Nägeli

1. Gloeothece membranacea (Rabenhorst) Fig. 1

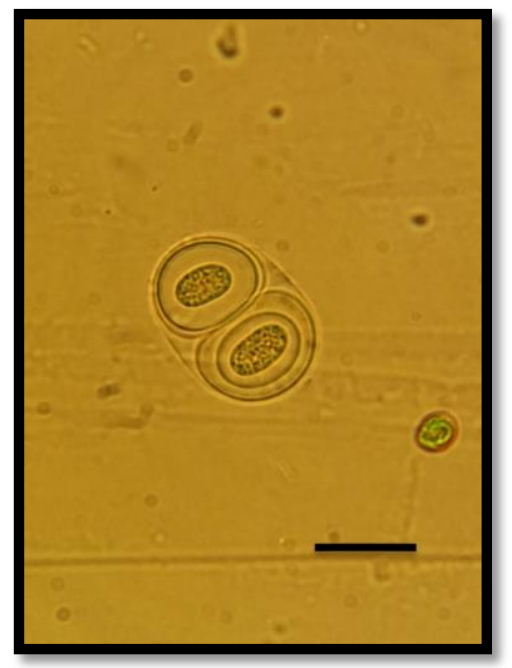

Basionym: Aphanocapsa membranacea Rabenhorst

Banerjee and Pal, Phytomorphology, 67(3\&4): 69, Fig. 1a, 2017; McGregor, Phytotaxa, 133(1): 23, pl. 4G, 28A, B, C, 2013; Whitton, 2011, Phylum Cyanobacteria (Cyanophyta) In: The Freshwater Algal Flora of the British Isles. An Identification Guide to Freshwater and Terrestrial Algae, 63; Martinez, 1984, A Checklist of Blue-Green Algae of the Philippines, 38.

Colonies consist of miniature sub-colonies enclosed together into mucilaginous envelopes, sometimes spherical or membranous; cells short cylindrical to oval with widely rounded ends, olive green to dark green in color, 6.0-7.5 $\mu \mathrm{m} \times 3.0$ $5.0 \mu \mathrm{m}$; formation of macroscopic cell aggregation sometimes occur; mucilaginous sheath around cells are colourless, lamellate and sometimes diffluent at the margin.

Found occurring as a bluish green patch on a bark surface associated with other green microalgae.

Specimen: LUZON, Laguna, Los Baños (Mt. Makiling Forest Reserve), E.DLR. Arguelles s.n. Photograph prepared from the mounted specimen.

Order Chroococcidiopsidales

Family Chroococcidiopsidaceae

Genus Chroococcidiopsis Geitler

1. Chroococcidiopsis cubana Komárek \& Hindák Fig. 2

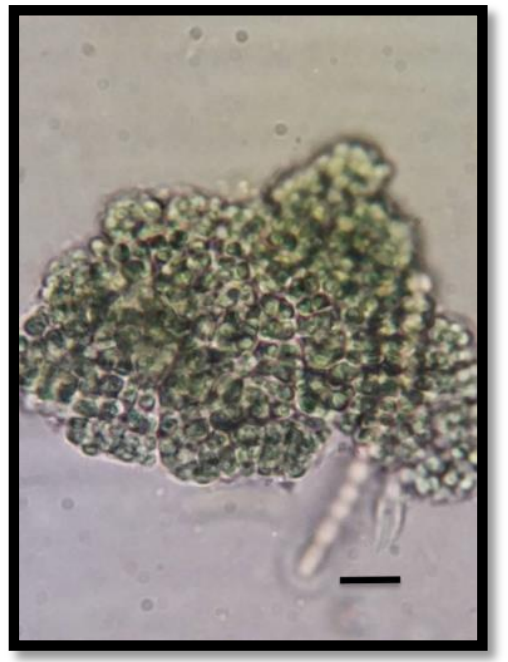

Komárek, 2003, Coccoid and Colonial Cyanobacteria In: Freshwater Algae of North America. Ecology and Classification, 104, fig. 20b; Komárek and Hindák, Archive für Hydrobiology, 13: 320, Fig. 27-36, 1975.

Cells are spherical or oval, solitary or in irregular clusters, blue-green in color protoplasts homogeneous or sometimes with granulated content. Cell reproduction is through formation of 8-32 endospores, developing by a simultaneous division of the algal cell protoplast and liberating through a small rupture at the mother cell wall. Endospores are spherical $(2.0-3.0 \mu \mathrm{m}$ in diameter); vegetative cells up to $10.0 \mu \mathrm{m}$ in diameter; sporangia (with differentiating protoplast) up to $25.0 \mu \mathrm{m}$ in diameter.

\section{A new record for the Philippines.}

Found occurring as a bluish green to blackish patch on moist bark sample associated with other green microalgae and cyanobacteria. The bark samples where the cyanobacterium was observed were collected from trees exposed to warm volcanic gases emanating from Mt. Makiling Mudspring.

Specimen: LUZON, Laguna, Los Baños (Mt. Makiling Mudspring, Mt. Makiling Forest Reserve), E.DLR. Arguelles s.n. Photograph prepared from the mounted specimen.

Order: Chroococcales

Family: Chroococcaceae

Genus: Chroococcus Nägeli

1. Chroococcus minutus (Kützing) Nägeli Fig. 3

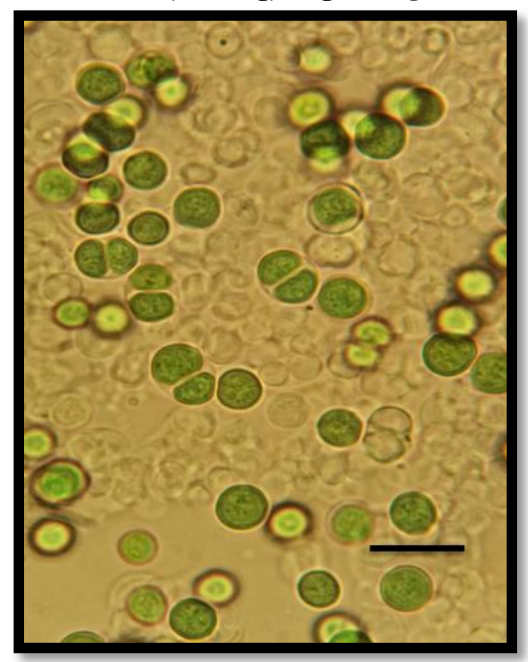

Basionym: Protococcus minutus Kützing

Arguelles, IAMURE International Journal of Ecology and Conservation, 17:30 pl. I. fig. 6, 2016; Singh, et al., Tropical Plant Research. 1(1): 28, g. 2C 2014; Komárek, Czech Polar Reports, 3 (2): 130, Fig. 7. 2013; Whitton, 2011, Phylum Cyanobacteria (Cyanophyta) In: The Freshwater Algal Flora of the British Isles. An Identification Guide to Freshwater and Terrestrial Algae, 54, pl. 11F; Martinez, 1984, A Checklist of Blue-Green Algae of the Philippines, 31: Desikachary, 1959, Cyanophyta, 104- 105, pl. 24, g.4 and pl. 26, g. 4 \& 15. 
Cells spherical or irregularly spherical usually occurring as single or in groups of 2-4 cells, blue-green in color; colonies enclosed in an amorphous, colorless, homogenous mucilage diffluent at the margin; 5.0-7.0 $\mu \mathrm{m}$ in diameter with sheath and 3.0-4.0 $\mu \mathrm{m}$ in diameter without sheath; protoplast is slightly granulated.

Found occurring as a blackish patch on a bark surface associated with other filamentous cyanobacteria.

Specimen: LUZON, Laguna, Los Baños (Mt. Makiling Forest Reserve), E.DLR Arguelles s.n. Photograph prepared from the mounted specimen.

Order: Oscillatoriales

Family: Coleofasciculaceae

Genus: Anagnostidinema Strunecký et al.

1. Anagnostidinema amphibium (C.Agardh ex Gomont) Strunecký,

Bohunická, J.R.Johansen \& J.Komárek Fig. 4

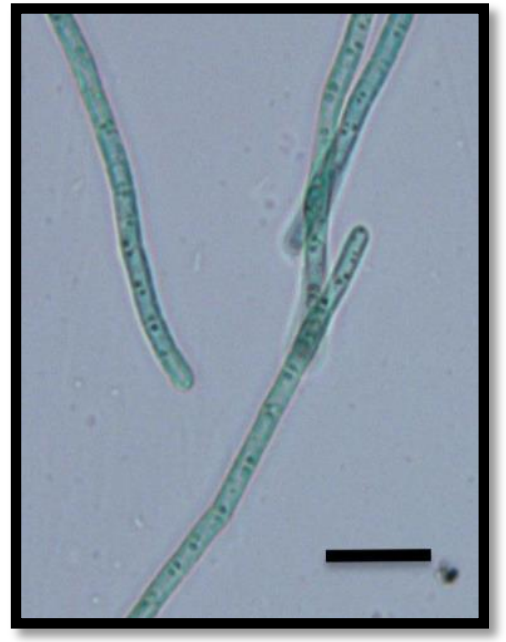

Basionym: Oscillatoria amphibia C. Agardh ex Gomont

McGregor, 2007. Freshwater Cyanoprokaryota of North-Eastern Australia 1: Oscillatoriales, 22: pl. 1I, Fig. 3D; Komárek and Anagnostidis, 2005

Cyanoprokaryota. 2. Teil: Oscillatoriales. Süßwasserflora von Mitteleuropa, 127: Fig. 136; = Oscillatoria amphibia C. Agardh ex Gomont, Whitton, 2011, Phylum Cyanobacteria (Cyanophyta) In: The Freshwater Algal Flora of the British Isles. An Identification Guide to Freshwater and Terrestrial Algae, 95; Martinez, 1984, A Checklist of Blue-Green Algae of the Philippines, 56; Velasquez, Philippine Journal of Science, 91(3): 289, pl. 2. Fig. 39, 1962

Trichomes light blue-green in color without sheath, isopolar, long, straight or sometimes flexuous, $1.5-2.0 \mu \mathrm{m}$ wide, cross walls are indistinct and no constricted; without or sometimes slightly attenuated at the posterior and anterior ends. Cells are longer than wide, 2.5-3.5 $\mu \mathrm{m}$ long, with 1 to 2 distinct cyanophycin granules on each of the cross wall. Apical cells are rounded, sometimes slightly bent and attenuated.

Found occurring as a brownish to blackish patch on a bark surface associated with other filamentous cyanobacteria.

Specimen: LUZON, Laguna, Los Baños (Mt. Makiling Forest Reserve), E.DLR Arguelles s.n. Photograph prepared from the mounted specimen.

Order: Synechococcales

Family: Pseudanabaenaceae

Genus: Pseudanabaena Lauterborn

1. Pseudanabaena galeata Böcher

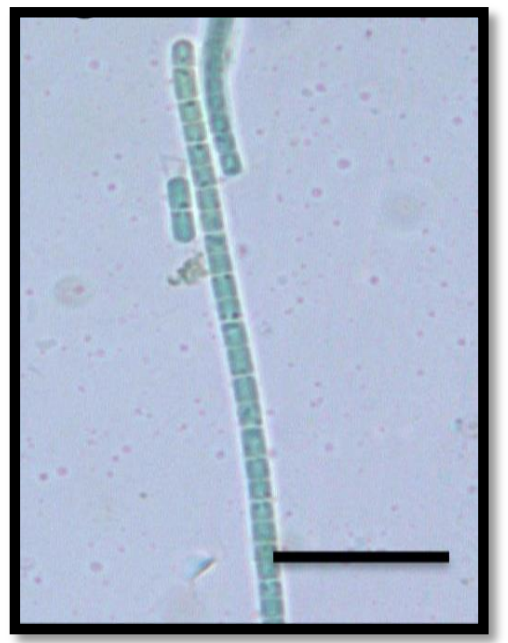

Komárek and Anagnostidis, 2005. Cyanoprokaryota. 2. Teil: Oscillatoriales Süßwasserflora von Mitteleuropa, 88: fig. 67.

Trichomes light blue-green in color and without a sheath, short, isopolar, flexuous, sometimes or rarely straight, $0.5-1.5 \mu \mathrm{m}$ wide, with 15-35 cells per filament, cross walls are constricted, not attenuated and capable of gliding motility. Cells are longer than wide, cylindrical, 2.5-3.0 $\mu \mathrm{m}$ long. Apical cells are canonically rounded with a crescent-shaped characteristic.

\section{A new record for the Philippines.}

Found occurring as a brownish to blackish patch on a bark surface associated with other filamentous cyanobacteria.

Specimen: LUZON, Laguna, Los Baños (Mt. Makiling Forest Reserve), E.DLR. Arguelles s.n. Photograph prepared from the mounted specimen.

\section{Pseudanabaena catenata Lauterborn Fig. 6}

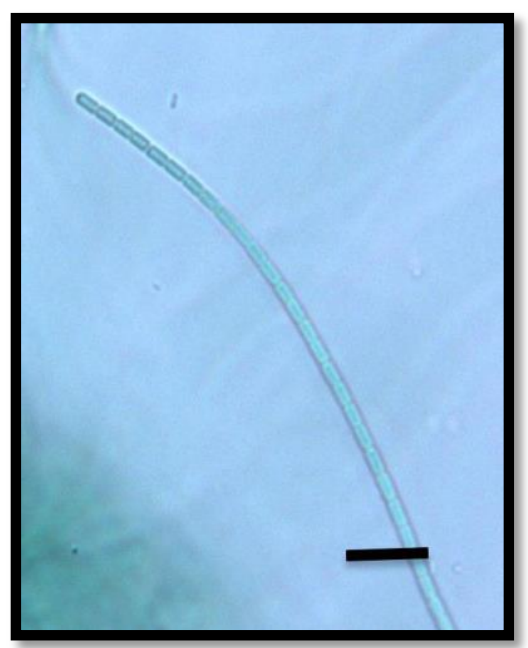

Park, 2012. Algal Flora of Korea: Cyanophyta: Cyanophyceae: Chroococcales, Oscillatoriales, 5(1): 48, Fig. 16G,17A,B; McGregor, 2007. Freshwater Cyanoprokaryota of North-Eastern Australia 1: Oscillatoriales, 36: fig. 2f; Komárek and Anagnostidis, 2005. Cyanoprokaryota. 2. Teil Oscillatoriales. Süßwasserflora von Mitteleuropa, 83: Fig. 59.

Cells usually 1.5-2.0 times longer than wide, cells are light blue-green in color, homogeneous protoplasm without aerotopes. Anterior end cells are rounded or sometimes slightly conical. Trichomes are solitary or sometimes cluster into a small tangle, straight, cylindrical and isopolar, usually with noticeable constrictions at the cross walls, 0.9-2.0 $\mu \mathrm{m}$ wide.

Found occurring as a brownish to blackish patch on a bark surface associated with other filamentous cyanobacteria.

\section{A new record for the Philippines.}

Specimen: LUZON, Laguna, Los Baños (Mt. Makiling Forest Reserve), E.DLR. Arguelles s.n. Photograph prepared from the mounted specimen.

Order Oscillatoriales 
Family Oscillatoriaceae

Genus Phormidium Kützing ex Gomont

1. Phormidium chalybeum (Mertens ex Gomont) Anagnostidis and Komárek Fig. 7

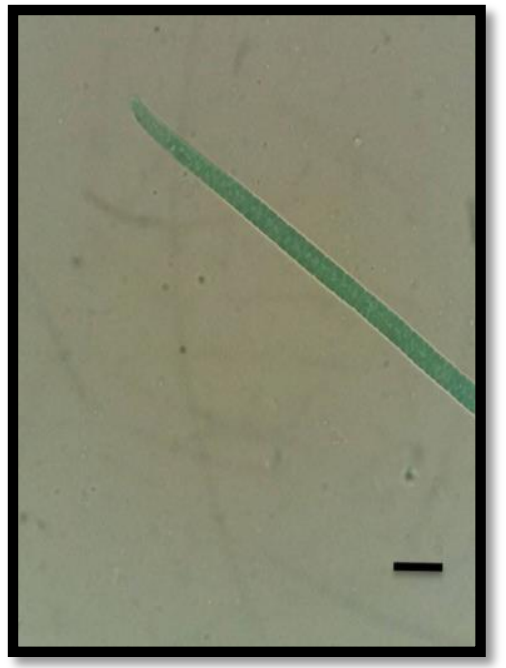

Basionym: Oscillatoria chalybea Mertens ex Gomont

McGregor, 2007. Freshwater Cyanoprokaryota of North-Eastern Australia 1: Oscillatoriales, 55: fig. 9d; Komárek and Anagnostidis, 2005. Cyanoprokaryota. 2. Teil: Oscillatoriales. Süßwasserflora von Mitteleuropa, 422 Fig. 604; = Oscillatoria chalybea Mertens ex Gomont, Martinez, 1984 A Checklist of Blue-Green Algae of the Philippines, 58; Velasquez, Philippine Journal of Science, 91(3): 289, pl. 1. Fig. 19, 1962

Trichomes blue-green in color, long and straight, 9.0-11.00 $\mu \mathrm{m}$ wide, constricted at cross walls, straight or slightly attenuated at the ends, capable of gliding motility. Cells are usually shorter than wide, (4.1) 5.0-9.0 $\mu \mathrm{m}$ long. Apical cells without a sheath, conically to broadly rounded and without a calyptra, protoplasm is finely granulated.

Found occurring as a bluish green to brownish patch on a bark surface associated with other filamentous cyanobacteria.

Specimen: LUZON, Laguna, Los Baños (Mt. Makiling Forest Reserve), E.DLR. Arguelles s.n. Photograph prepared from the mounted specimen.

Order: Nostocales

Family: Hapalosiphonaceae

Genus: Hapalosiphon Nägeli ex É. Bornet \& C. Flahault 1. Hapalosiphon welwitschii West \& G.S.West

Fig. 8

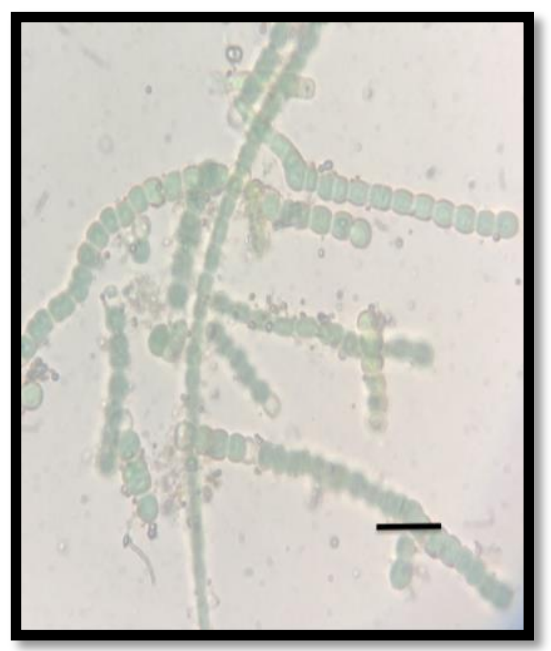

Arguelles, Tropical Life Sciences Research, 30(1): 7, pl. I. Fig.7, 2019; Arguelles, IAMURE International Journal of Ecology and Conservation, 17:30, pl. I. fig. 5, 2016; Saha, et al., Indian Journal of Microbiology, 47: 219, fig. 29, 2007; Martinez, 1984, A Checklist of Blue-Green Algae of the Philippines, 39; Desikachary, 1959, Cyanophyta, 588, pl. 137, fig. 5.
Trichomes are uniserial and irregularly arcuate exhibiting true branches, 4.0-4.5 $\mu \mathrm{m}$ broad, slightly constricted at the crosswalls, anterior end is not attenuated and capitated; cells are cylindrical and blue-green in color, 2.0-3.0 $\mu \mathrm{m}$ long and 4.0 $5.0 \mu \mathrm{m}$ wide, protoplasm not granular, septa slightly granulated, end cells rounded; sheaths are thin and colorless; lateral branches short, with similar cellular dimensions as the main filament.

Found occurring as a brownish to bluish-green patch on a bark surface associated with other green microalgae.

Specimen: LUZON, Laguna, Los Baños (Mt. Makiling Forest Reserve), E.DLR. Arguelles s.n. Photograph prepared from the mounted specimen.

Family: Nostocaceae

Genus: Nostoc Vaucher ex Bornet \& Flahault

1. Nostoc commune Vaucher ex Bornet \& Flahault Fig. 9

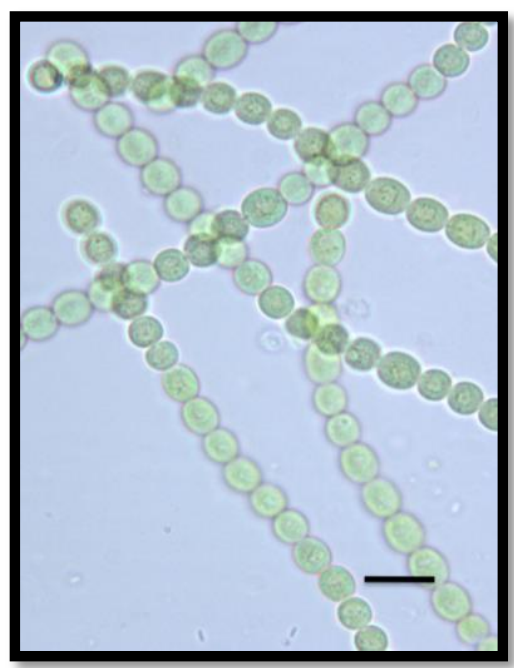

Martinez-Goss, et al., The Philippine Scientist, 51: 78, pl. III, fig. 5, 2014 Komárek et al., 2003, Filamentous Cyanobacteria In: Freshwater Algae of North America. Ecology and Classification, 177, fig. 34e; Martinez, 1984, A Checklist of Blue-Green Algae of the Philippines, 52; Velasquez, Philippine Journal of Science, 91(3): 342, pl. 8. Fig. 105, 1962; Desikachary, 1959, Cyanophyta, 387, pl. 68, Fig. 3.

Cells are blue-green in color, barrel-shaped or nearly spherical; trichomes are constricted at the crosswalls, $3.0-4.5 \mu \mathrm{m}$ broad, not attenuated at the ends; cells $5.0 \mu \mathrm{m}$ long, mostly shorter than broad; heterocytes nearly spherical, about 6.0 $\mu \mathrm{m}$ broad; filaments are entangled and aggregate at maturity in a mass, macroscopically or microscopically.

Found occurring as a brownish to blackish gelatinous patch on a bark surface associated with other filamentous cyanobacteria.

Specimen: LUZON, Laguna, Los Baños (Mt. Makiling Forest Reserve), E.DLR Arguelles s.n. Photograph prepared from the mounted specimen.

\section{Chlorophyta}

Class: Chlorophyceae

Order: Chlamydomonodales

Family: Chlorococcaceae

Genus: Chlorococcum Meneghini

1. Chlorococcum infusionum (Schrank) Meneghini Fig. 10 


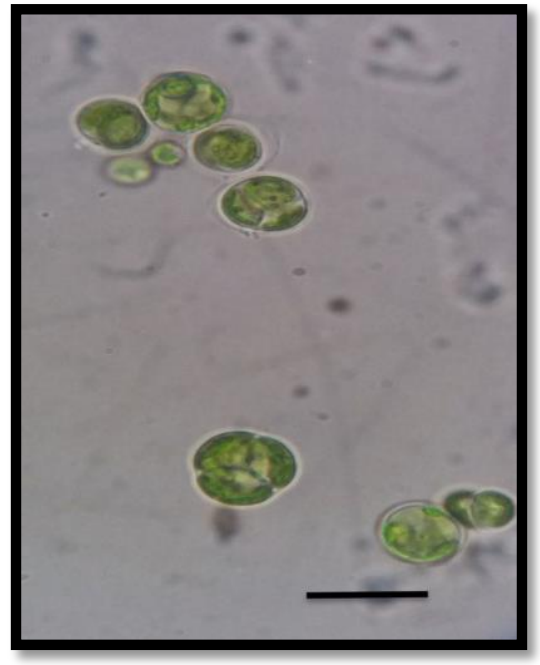

Synonym: Chlorococcum humicola (Nägeli) Rabenhorst 1868 Basionym: Lepra infusionum Schrank

Arguelles, IAMURE International Journal of Ecology and Conservation, 17: 32, pl. I. Fig. 7, 2016; John, 2011, Phylum Chlorophyta (Green Algae) In: The Freshwater Algal Flora of the British Isles. An Identification Guide to Freshwater and Terrestrial Algae, 414, pl. 103L; Samad and Adhikary, Algae, 23(2): 91, pl. 1 Fig. 1., 2008; Zafaralla, 1998, Microalgae of Taal Lake, 33, pl 8e.f; Pantastico, 1977, Taxonomy of the Freshwater Algae of Laguna de Bay and Vicinity, 76, pl. VII, Fig 1; Prescott, 1962, Algae of the Western Great Lakes Area, 280, pl. 45, Fig. 1

Cells are spherical, greenish in color, usually occurring as solitary but sometimes several cells are packed together to form a mass of compact cells; parietal chloroplasts are present in the cell with a single pyrenoid nearly covering the entire cell; cells 7.0-9.0 $\mu \mathrm{m}$ in diameter; zoospores are cylindrical or oval in shape, 2.0-4.5 um wide and 5.0-11.5 um long, characterized by having a papilla with an eye spot and contractile vacuoles.

Found occurring as a greenish patch on a bark surface associated with other filamentous cyanobacteria.

Specimen: LUZON, Laguna, Los Baños (Mt. Makiling Forest Reserve), E.DLR. Arguelles s.n. Photograph prepared from the mounted specimen.

Class: Trebouxiophyceae

Order: Chlorellales

Family: Chlorellaceae

Genus: Parachlorella L. Krienitz, E.H. Hegewald, Hepperle, V. Huss, T.

Rohr \& M. Wolf

1. Parachlorella kessleri (Fott \& Nováková) L. Krienitz, E.H.

Hegewald, Hepperle, V. Huss, T. Rohr \& M. Wolf Fig. 11

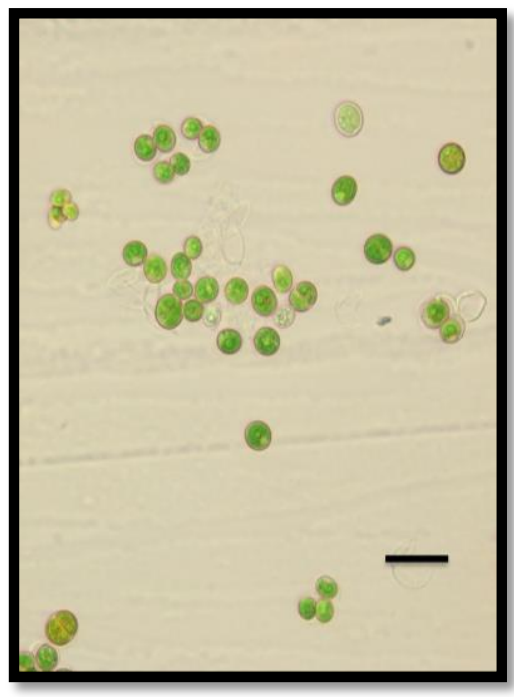

Basionym: Chlorella kessleri Fott \& Nováková
Krienitz, et al., Phycologia, 43: 532, Fig. 8, 2004; = Chlorella kessleri Fott \& Nováková, Fott and Nováková, 1969, A Monograph of the Genus Chlorella. The Freshwater Species In: Studies in Phycology, 26-28, pl. 4.

The vegetative cells are either spherical or ellipsoidal with thin cell wall chloroplast is single, mantle-shaped with clearly visible spherical pyrenoid occupying a basal zone of the cell; young cells are either ellipsoidal or spherical, 4.5-6.0 $\mu \mathrm{m}$ in diameter; cellular reproduction is by formation of 4 or 8 autospores of the ellipsoidal shape (2.0-3.5 x 3.0-4.5 $\mu \mathrm{m}$ in size), set free by a broad opening or a rupture of mother cell wall.

Found occurring as a greenish patch on a bark surface associated with other filamentous cyanobacteria.

\section{A new record for the Philippines.}

Specimen: LUZON, Laguna, Los Baños (Mt. Makiling Forest Reserve), E.DLR. Arguelles s.n. Photograph prepared from the mounted specimen.

Order Prasiolales

Family Prasiolaceae

Genus Desmococcus F. Brand

1. Desmococcus olivaceus (Persoon ex Archerson) J. R. Laundon

Fig. 12

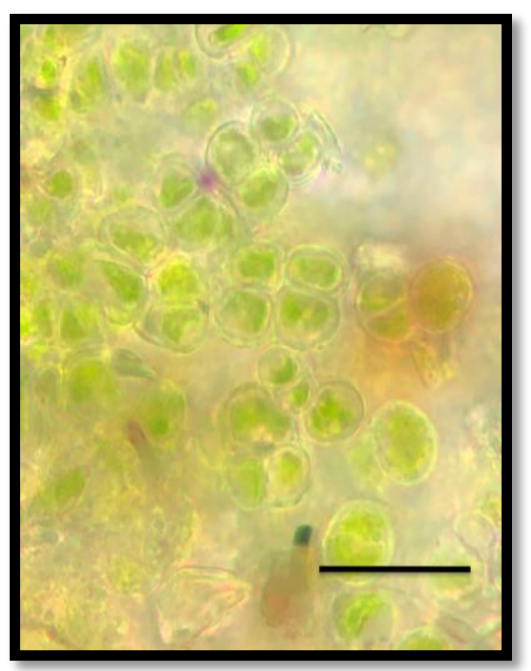

Basionym: Lepraria olivacea Persoon ex Archerson

Bhakta, et al., Phykos, 44(1): 14, Pl. 3, Fig. 10, 2014; John, 2011, Phylum Chlorophyta (Green Algae). Orders Chaetophorales, Microsporales,

Ulotrichales. In: The Freshwater Algal Flora of the British Isles. An Identification Guide to Freshwater and Terrestrial Algae, 530, pl. 136E Lemes-Da-Silva, et al., Revista Brasileira de Botanica. 33(2): 271, Fig. 2-4, 2010; Broady and Ingerfield, European Journal of Phycology. 28: 27, Fig. 3A-H, 9, 1993.

Cells are in sarcinoid aggregates (2-4 celled colonies), 4.0-8.0 $\mu \mathrm{m}$ in diameter; cells occur as spherical, hemispherical or irregular, 2.0-5.0 $\mu \mathrm{m}$ diameter; chloroplasts are observed to be parietal; pyrenoid is indistinguishable; aplanosporangia are spherical with an ornamented wall.

Found occurring as a greenish patch on a bark surface associated with other filamentous cyanobacteria.

\section{A new record for the Philippines.}

Specimen: LUZON, Laguna, Los Baños (Mt. Makiling Forest Reserve), E.DLR. Arguelles s.n. Photograph prepared from the mounted specimen.

Genus Apatococcus F. Brand

1. Apatococcus lobatus (Chodat) J.B. Petersen Fig. 13 


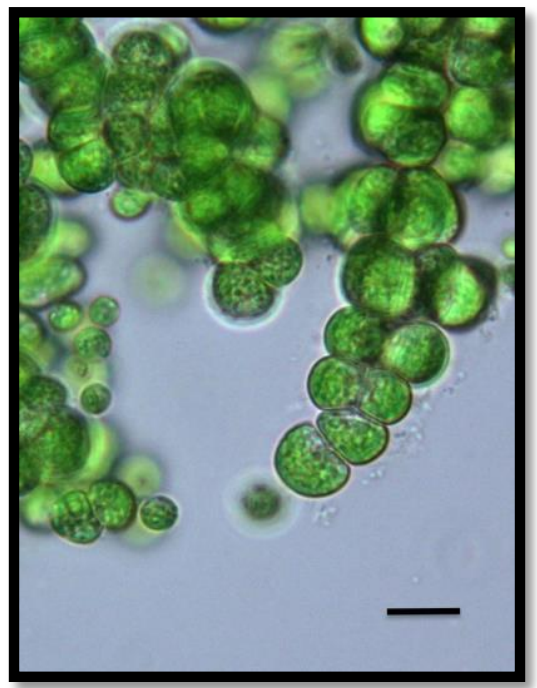

Basionym: Pleurococcus lobatus Chodat

John, 2011, Phylum Chlorophyta (Green Algae). Orders Chaetophorales, Microsporales, Ulotrichales. In: The Freshwater Algal Flora of the British Isles. An Identification Guide to Freshwater and Terrestrial Algae, 525, pl. 136A.

Cells solitary or clumped together forming 2-, 3-, or 4- celled packets, frequently clustered together; cells globose to somewhat compressed, 7.0-13.0 $\mu \mathrm{m}$ across, walls regularly thickening with age; large chloroplasts either lobed or plateshaped.

Found occurring as a greenish patch on a bark surface associated with other filamentous cyanobacteria and green microalgae.

\section{A new record for the Philippines.}

Specimen: LUZON, Laguna, Los Baños (Mt. Makiling Forest Reserve), E.DLR Arguelles s.n. Photograph prepared from the mounted specimen.

Class: Ulvophyceae

Order: Trentepohliales

Family: Trentepohliaceae

Genus: Trentepohlia Martiu4

1. Trentehpolia monilia De Wildeman Fig. 14

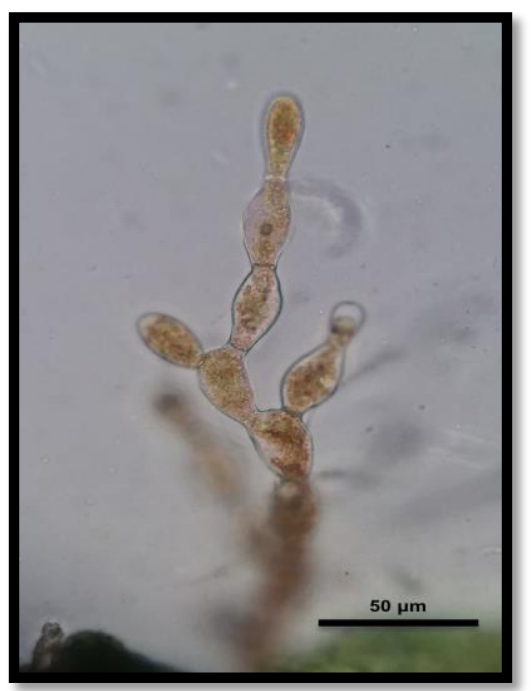

Synonym: Trentehpolia rigidula (J. Müler) Hariot

Salleh and Milow, Natural History Bulletin Siam Society, 41:63, Fig. 1(a-e), 2, 1993.

Filaments possess a unique prostrate and erect branching system. Cells orange or green in color, ovoid and rarely spherical, $17.0-41.0 \mu \mathrm{m}$ long and $7.0-16.0 \mu \mathrm{m}$ wide. The cell wall is smooth 1.5-2.0 $\mu \mathrm{m}$ thick. Sporangia pedicellate, produced on the terminal portion of erect branches, orange and sometimes greenish in color, spherical, 19.0-23.0 $\mu \mathrm{m}$ in diameter. Stalk cells are bottle-shape (38.0-43.5 $\mu \mathrm{m}$ long and 7.5-15.0 $\mu \mathrm{m}$ wide) with a bent neck; orange, yellowish-green or hyaline in color.

Found occurring as a greenish to orange patch on a bark surface associated with other filamentous cyanobacteria and green microalgae.

Specimen: LUZON, Laguna, Los Baños (Mt. Makiling Forest Reserve), E.DLR. Arguelles s.n. Photograph prepared from the mounted specimen.

\section{Charophyta}

Class: Klebsormidiophyceae

Order: Klebsormidiales

Family: Klebsormidiaceae

Genus: Klebsormidium P.C. Silva, Mattox \& W.H. Blackwell

1. Klebsormidium flaccidum (Kützing) P.C. Silva, K.R. Mattox \& W.H. Blackwell Fig. 15

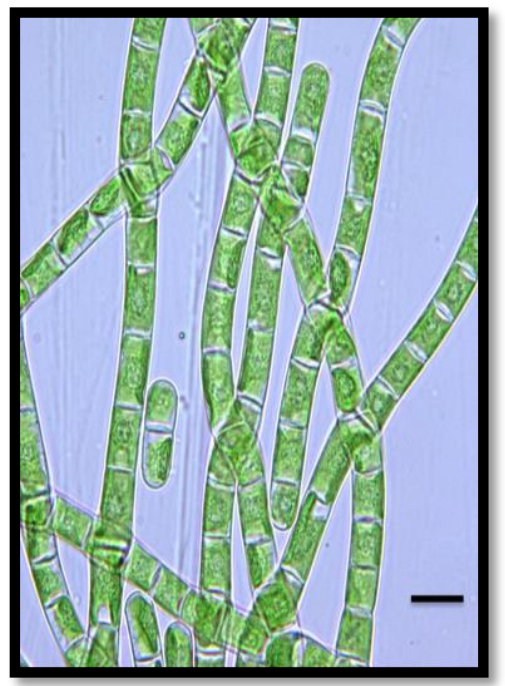

Basionym: Ulothrix flaccida Kützing

Mikhailyuk, et al., Journal of Phycology. 755, Fig. 2a-f, 2015; Kim and Lee Journal of Ecology and Environment, 335, Fig. 6c, 2014; John, 2011, Phylum Chlorophyta (Green Algae) In: The Freshwater Algal Flora of the British Isles. An Identification Guide to Freshwater and Terrestrial Algae, 556, pl. 138J; Flechtner, et al., Western North American Naturalist. 410 Fig. 5, 2008; $\quad$ Ortega-Calvo, et al., Nova Hedwigia. 246, pl. 3, Fig. 32, 1993; = Ulothrix flaccida Kützing, Pantastico, 1977, Taxonomy of the Freshwater Algae of Laguna de Bay and Vicinity, 143, pl. XI, Fig 1.

Filaments are slightly constricted at the crosswalls; occurring naturally as long filaments with high tendency to separate and shatter apart into smaller fragments; cells are cylindrical to oval in shape with rounded ends, $10.0 \mu \mathrm{m}$ long and $4.0 \mu \mathrm{m}$ wide; cell wall moderately thickened; chloroplasts are parietal and band-shaped containing one pyrenoid covering $1 / 2-2 / 3$ of the cell inner surface.

Found occurring as a greenish mat on a bark surface associated with other filamentous cyanobacteria.

Specimen: LUZON, Laguna, Los Baños (Mt. Makiling Forest Reserve), E.DLR. Arguelles s.n. Photograph prepared from the mounted specimen.

In spite of the fact that the total area studied is relatively small in comparison with the country area and also considering that just one ecosystem was studied, the present survey showed a diverse collection of corticolous microalgae and cyanobacteria in the sampling area. A total of 15 taxa belonging to the class Cyanophyceae, Chlorophyceae, Trebouxiophyceae, Ulvophyceae, and Klebsormidiophyceae were described in detail including a short description of their habitat and place of collection. This study reported the occurrence of six corticolous algae namely: Chroococcidiopsis cubana Komárek \& Hindák, Pseudanabaena galeata Böcher, Pseudanabaena catenata Lauterborn, Parachlorella kessleri (Fott \& Nováková) L. Krienitz, E.H. Hegewald, Hepperle, V. Huss, T. Rohr \& M. Wolf, Desmococcus olivaceus (Persoon ex Archerson) J. R. Laundon, and Apatococcus lobatus (Chodat) J.B. Petersen for the first time in the Philippines. The corticolous algal flora observed in this survey is not very much distinct from those of other regions, several species and genera found during the survey have been also described in prior studies on corticolous algae in different world regions. Bhakta, et al., (2014) reported 19 corticolous microalgae and cyanobacteria Similipal Biosphere reserve, Mayurbhanj, Odisha, India and two of them (Desmococcus olivaceus and Nostoc commune) were also observed in this study. Desmococcus olivaceus and the genus Klebsormidium 
were observed in aerial algal biofilms collected from the tropical forest remnants in the northwest region of São Paulo State, Brazil by Lemes-Da-Silva et al., (2010), besides another seven species of green microalgae. In collation with the preliminary survey done by Arguelles, (2016) on the Philippine subaerial epilithic algae in Los Baños, Laguna, three species (Chlorococcum infusionum, Hapalosiphon welwitschii, and Chroococcus minutus) are shared.

The results show that representative taxa coming from green microalgae and cyanobacteria mainly represented the algal communities observed in the studied environment. Different adaptation strategies against dehydration in aerial habitats such as the presence of sporopollenin-like compounds in the cell wall and a special carbohydrate and alcohol pattern contributed to the successful growth and proliferation of corticolous microalgae and cyanobacteria in such extreme environments (Lemes-Da-Silva, et al., 2010). On the other hand, ecophysiological protective mechanisms to avoid excessive irradiances such as the production of carotenoids and thallus formation are also considered important mechanisms being used by corticolous algae in the aero-terrestrial environment (Lemes-Da-Silva, et al., 2010).

Due to the limited number of studies on corticolous algae in the tropical regions and especially in the Philippine archipelago, these records can be considered an important contribution to the knowledge about the diversity and geographica distribution of microalgae and cyanobacteria in the country. However, morphology-based taxonomy of species has been considered sometimes problematic to species identification. Therefore, it is suggested that detailed studies focusing on molecular data should be conducted to give a more reliable and accurate taxonomic delimitation.

\section{CONCLUSION}

The present study reported a compilation of some noteworthy corticolous microalgae and cyanobacteria in bark surfaces of trees found at Mt. Makiling Forest Reserve. Taxonomic account of this group of microorganism builds up important information on algal diversity as part of the living resources of the Philippines. The results of this study will add to the pool of data important in understanding the ecology and habitat distribution of microalgae and cyanobacteria in the Philippines.

Acknowledgments: The author express gratitude for the support of the National Institute of Molecular Biology and Biotechnology (BIOTECH) who provided the equipment as well as other chemicals needed for the completion of the study. The help of Mr. Marc Villarubi for the preparation of the algal photomicrographs is acknowledged with gratitude.

\section{REFERENCES}

ARGUELLES, E.D.L.R. 2019. Systematic study of some epiphytic algae (nondiatoms) on the submerged parts of water hyacinth [Eichhornia crassipes (Mart.) Solms-Loubach] found in Laguna de Bay, Philippines. Tropical Life Sciences Research, 30(1): 1-21. https://doi.org/10.21315/t1sr2019.30.1.1

ARGUELLES, E.D.L.R., LAURENA, A.C., MONSALUD, R.G., MARTINEZ GOSS, M.R. 2018. Fatty acid profile and fuel-derived physico- chemica properties of biodiesel obtained from an indigenous green microalga Desmodesmus sp. (I-AU1), as potential source of renewable lipid and high quality biodiesel. Journal of Applied Phycology. 30: 411-419. https://doi.org/10.1007/s10811-017-1264-6

ARGUELLES, E.D.L.R. 2016. Morphotaxonomic account of epilithic microalgae and cyanobacteria in Los Baños, Laguna (Philippines). IAMURE International Journal of Ecology and Conservation, 17: 22-39.

ARGUELLES, E.D.L.R., MARTINEZ-GOSS, M.R., SHIN, W. 2014. Some noteworthy photosynthetic euglenophytes from Laguna and vicinities. The Philippine Scientist, 51: 1-36.

BANERJEE, S., PAL, R. 2017. Morphotaxonomic Study of blue green algae from pristine areas of west Bengal with special reference to SEM studies of different morphotypes and four new reports. Phytomorphology, 67(3\&4): 67-83. BHAKTA, S., PATTANAIK, L., DUTTA, P., SAHU, E. AND BASTIA, A.K 2014. Diversity of corticolous algae from Similipal biosphere reserve, Mayurbhanj, Odisha. Phykos. 44 (1): 9-16.

BROADY, P.A., INGERFELD, M. 1993. Three new species and a new record of Chaetophoracean (Chlorophyta) algae from terrestrial habitats in Antartica. European Journal of Phycology, 28: 25-31. https://doi.org/10.1080/09670269300650041

DESIKACHARY, T. V. 1959. Cyanophyta. I.C.A.R. monograph on Algae. New Delhi, $686 \mathrm{pp}$.

ETTL, H., GÄRTNER, G. 2013. Syllabus der Boden-, Luft- und Flechtenalgen. 16, Gustav Fischer Verlag, Stuttgart, Jena, $721 \mathrm{pp}$.

FLECHTNER, V.R., JOHANSEN, J.R., BELNAP J. 2008. The biological soil crusts of the San Nicolas Island: enigmatic algae from a geographically isolated ecosystem. Western North American Naturalist, 68(4): 405-436. https://doi.org/10.3398/1527-0904-68.4.405
FOTT, B., NOVÁKOVÁ, M. 1969. A monograph of the genus Chlorella. The Freshwater Species In: Studies in Phycology (Ed. By B. Fott), pp. 10-74, Academia, Prague.

GUIRY M.D. IN GUIRY M.D., GUIRY G.M. 2018. AlgaeBase. World-wide electronic publication, National University of Ireland, Galway. http://www.algaebase.org; searched on 02 January 2018.

JOHN, D.M., TSARENKO, P.M. 2011. Phylum Chlorophyta (Green Algae), In: John, D.M., B.A., Whitton, and Brook, A.J. (ed.), The freshwater algal flora of the British Isles. An identification guide to freshwater and terrestrial algae, Cambridge: Cambridge University Press. 327-409 pp.

KIM, J.W., LEE, O.M. 2014. The distribution and three newly reported species of aerial algae at Mt. Gwanggyo, Korea. Journal of Ecology and Environment. 37(4): 327-339. http://dx.doi.org/10.5141/ecoenv.2014.035

KRIENITZ, L., HEGEWALD, E.H., HEPPERLE, D., HUSS, V.A.R., ROHR, T. WOLF, M. 2004. Phylogenetic relationship of Chlorella and Parachlorella gen. nov. (Chlorophyta, Trebouxiophyceae). Phycologia 43: 529-542. https://doi.org/10.2216/i0031-8884-43-5-529.1

KOMÁREK, J., HINDÁK, F. 1975. Taxonomy of the new isolated strains of Chroococcidiopsis (Cyanophyceae). Archiv für Hydrobiologie. 13: 311-329.

KOMÁREK, J. 2003. Coccoid and Colonial Cyanobacteria, In: Wehr, J.D. and Sheath, R.G. Freshwater Algae of North America. Ecology and Classification, USA, Academic Press. 59-116 pp.

KOMÁREK, J., Kling, H., Komárková. J. 2003. Filamentous Cyanobacteria, In: Wehr, J.D. and Sheath, R.G. Freshwater Algae of North America. Ecology and Classification, USA, Academic Press. 117-196 pp.

KOMÁREK, J., ANAGNOSTIDIS, K. 2005. Cyanoprokaryota, II. Teil Oscillatoriales, Band 19/2, Süßwasserflora von Mitteleuropa, Elsevier, Munchen, 759 pp.is:

LEMES-DA-SILVA, N.M., ZANINI BRANCO, L. H., NECCHI-JUNIOR, O 2010. Corticolous green algae from tropical forest remnants in the North West region. Revista Brasileira de Botanica, 33: 215-226 http://dx.doi.org/10.1590/S0100-84042010000200003

LÓPEZ-BAUTISTA, J. M., RINDI, F., GUIRY, M. D. 2006. Molecular systematics of the subaerial green algal order Trentepohliales: an assessment based on morphological and molecular data. International Journal of Systematic and Evolutionary $\quad$ Microbiology, 56: 1709-1715 https://dx.doi.org/10.1099/ijs.0.63990-0

LOPEZ-BAUTISTA, J.M., RINDI, F., CASAMATTA, D. 2007. The systematics of subaerial algae. In: Seckbach, J. (ed): Algae and cyanobacteria in extreme environments. Springer, Netherlands, 599-617 pp.

MARTINEZ-GOSS M.R., TORRETA N., NACORDA, J.O.O., MENDOZA C.D. 2014. The algal culture collection at the University of the Philippines Los Baños-Museum of Natural History (ACC-UPLB-MNH). The Philippine Scientist 51:66-103.

MARTINEZ, M.R. 1984. A checklist of blue-green algae of the Philippines. National Institute of Molecular Biology and Biotechnology (BIOTECH) University of the Philippines Los Baños. 96pp.

MCGREGOR, G. B. 2013. Freshwater Cyanobacteria from North-Eastern $\begin{array}{llll}\text { Australia: } & \text { 2. Chroococcales. } & \text { Phytotaxa, 133: } & 130\end{array}$ http://dx.doi.org/10.11646/phytotaxa.133.1.1

MCGREGOR, G. B. 2007. Freshwater Cyanoprokaryota of North-Eastern Australia 1: Oscillatoriales. CSIRO Publishing, Canberra. $124 \mathrm{pp}$.

MIKHAILYUK T., GLASER, K., HOLZINGER, A., KARSTEN U. 2015 Biodiversity of Klebsormidium (Streptophyta) from alpine biological soil crusts (Alps, Tyrol, Austria, and Italy). Journal of Phycology, 51: 750-767. https://dx.doi.org/10.1111\%2Fipy.12316

MOLLENHAUER, D., BÜDEL, B., MOLLENHAUER, R. 1994. Approaches to species delimitations in the genus Nostoc Vaucher 1803 ex Bornet et Flahault 1888. Algological Studies, 75: 189-209.

NEUSTUPA, J., SKKALOUD, P. 2008. Diversity of subaerial algae and cyanobacteria on tree bark in tropical mountain habitats. Biologia, 63: 806812. SEE https://doi.org/10.2478/s11756-008-0102-3

NEUSTUPA, J., ŠKALOUD, P. 2010. Diversity of subaerial algae and cyanobacteria on tree bark and wood in the low land tropical forests of Singapore. Plant Ecology and Evolution, 143: 51-62. https://doi.org/10.2478/s11756-008-0102-3

NEUSTUPA, J., ŠTIFTEROVÁ, A. 2013. Distribution patterns of subaerial corticolous microalgae in two European regions. Plant Ecology and Evolution, 146: 279- 289. http://dx.doi.org/10.5091/plecevo.2013.862

ORTEGA-CALVO, J.J., SANCHEZ-CASTILLO, P.M., HERNANDEZMARINE, M., SAIZ-JIMENEZ, C. 1993. Isolation and characterization of epilithic chlorophyta and cyanobacteria from two Spanish cathedrals (Salamanca and Toledo). Nova Hedwigia, 57: 239-253.

PANTASTICO, J.B. 1977. Taxonomy of the fresh-water algae of Laguna de Bay and vicinity. Bicutan, Taguig, Metro Manila. National Research Council of the Philippines. 251p

PARK, J.G. 2012. Algal Flora of Korea: Cyanophyta: Cyanophyceae: Chroococcales, Oscillatoriales: NIBR Ministry of Environment, Incheon. 71 pp. PRESCOTT, G.W. 1962. Algae of the western great lakes area, Dubuque, Iowa, Wm. C. Brown Co. Publishers. 853p. 
SAHA, S.K., DAS, R., BORA, K.N., UMA, L. 2007. Biodiversity of epilithic cyanobacteria from freshwater streams of Kakoijana reserve forest, Assam, India. Indian Journal of Microbiology, 47: 219-232. https://doi.org/10.1007/s12088 007-0043-5

SALLEH, A., MILLOW, P. 1993. Notes on Trentepohlia monilia de Wildeman (Chlorophyta, Ulothrichales) from the campus of the University of Malaya, Kuala Lumpur, Malaysia. Natural History Bulletin Siam Society, 41: 63-65.

SALlEH, A., MILlOW, P. 1999. Notes on Trentepohlia dialepta (Nylander) Hariot (Trenteopohliaceae, Chlorophyta) and sporangia of some other species of Malaysia. Micronesica, 31: 373-378.

SAMAD, L.K., ADHIKARY, S.P. 2008. Diversity of microalgae and cyanobacteria on building facades and monuments in India. Algae, 23(2): 91-114. https://doi.org/10.4490/ALGAE.2008.23.2.091

SINGH, A., TIWARI, V., MOHAN, J. 2014. Chroococcales in river Ganga at Jajmau Ghat, Kanpur. Tropical Plant Research, 1(1): 28-30.

STAINER, R.Y, KUNIWASA, R., MANDE, M., COHEN-BIZAIER, G. 1971 Purification and properties of unicellular blue-green algae (Order Choococcales). Bacteriological Reviews, 35: 171-205.

ŠTIFTEROVÁ, A. NEUSTUPA J. 2015. Community structure of corticolous microalgae within a single forest stand: evaluating the effects of bark surface $\mathrm{pH}$ and tree species. Fottea, Olomouc, 15(2): 113-122.

VELASQUEZ, G.T. 1962. The blue green-algae of the Philippines. Philippine Journal of Science, 91(3): 267-380.

WHITTON, B.A. 2011. Phylum Cyanobacteria (Cyanophyta). In: John, D.M. Whitton, B.A. and Brook, A.J. (Eds.), The freshwater algal flora of the British Isles. An identification guide to freshwater and terrestrial algae. Cambridge University Press, New York. pp. 31-158.

ZAFARALLA, M.T. 1998. Microalgae of Taal Lake. Bicutan, Taguig, Metro Manila. National Academy of Science and Technology. 66pp.

ZAMMIT, G., BILLI, D., SHUBERT, E., KASTOVSKY, J., ALBERTANO, P. 2011. The biodiversity of subaerophytic phototrophic bioflims from Maltase hypogea. Fottea, 11: 187-201. 